\title{
THE ADOPTION OF COMMUNICATION AND INFORMATION TECHNOLOGIES AND THE LOCAL DEVELOPMENT
}

\author{
Maria Teresa Borges Tiago ${ }^{1}$, João Pedro Couto², Maria Manuela dos Santos Natárioº \\ Ascensão Maria Martins Braga ${ }^{4}$ \\ ${ }^{1,2}$ University of the Azorest, Rua da Mãe de Deus, 9500 Azores, Portugal; ${ }^{3,}{ }^{4}$ Guarda Polytechnics Institute, \\ Av. Dr. Francisco Sá Carneiro, 50, 6300- 559 Guarda, Portugal. E-mails: ${ }^{1}$ mariaborges@notes.uac.pt, \\ ${ }^{2}$ jpedro@notes.uac.pt, ${ }^{3}$ m.natario@ipg.pt, ${ }^{4}$ sbraga@ipg.pt
}

Received 5 October 2006; accepted 15 January 2007

\begin{abstract}
This paper examines the imbalances in the availability and usage of communication and information technology infrastructure. These imbalances could be broadly attributed to differences in funding, management and technical expertise, exposure and awareness of available technologies, training, and other infrastructures like R\&D institutions. In our sample, the imbalances could be broadly attributed not only to differences in such factors as industry, dimension, management education, but also to lack of cooperation, workers mobility and reduced markets which are common factors in disfavoured regions.
\end{abstract}

Keywords: Innovation, Innovation Systems, Innovative Capacity.

\section{Introduction}

Since the 1980s the European Union and national states have begun to realise the importance of information and knowledge as valuable resources, both nationally and within organisations, especially in rural and disfavoured areas.

These efforts lead to the development of National Information and Communication Infrastructure (NICI) policies, plans and strategies that could be used to enhance the role of information and communication technologies (ICTs) in facilitating the socio-economic development process (OCDE, 1997).

The new information and communication technologies are of key importance to the inhabitants of the regions, as the Committee of the Regions underlined in its opinion on measures to promote information and communication technologies. Not only is there a significant digital divide between European Union countries, but also within these countries many regions are entirely "off the grid" (Persaud, 2001; Kowalczykowski, 2002).

The use of information technologies is helping to strengthen economic and social cohesion. It is also improving the economic competitiveness of the regions. However the territory development process depends on the decisions of governance system and on other economic actors. It results from the historic process of accumulation of attitudes and decisions and experience.

Regions situated far from large cities and densely populated urban areas are now, thanks to the ICT, able to gain such access to the same up-to-date information as is available in urban areas.

Information and Communication Technology (ICT) is an increasingly powerful tool for participating in global markets; promoting political accountability; improving the delivery of basic services; and enhancing local development opportunities. Innovation is a key for the sustainable development, competitiveness and depends on the access to the tacit and codified information and knowledge of ICT being a way to contribute to easier access.

According to Neto and Barroso (2003) the relationship between the adoption of Information and Com- 
munication Technologies (ICTs) in the companies and the regional development represents one potential form that permits regional territories to project and position themselves and favour the emergence of new organizations and relationship configurations. In an increased information society ICT constitutes a regional development instrument through information flows developed (Courlet and Pecqueur, 1991).

In the recent decades EU and national states have planned policies to introduce ICT in rural areas in order to permit access to new and distant markets, to break isolation and increase competitiveness. The adoption of ICT by the companies reflects the power of the regional policies adopted. In order to successfully implement policies, factors such as the organizational, institutional and socio-cultural environment of the regions and rural enterprises should be taken into consideration (Georgoudaki et al., 2003: p 1).

According to OECD (2001), Neto (2002), Georgoudaki, et al. (2003) it is frequently believed that ICTs offer new means for revitalization of rural economies that for a long period have been under a severe economic decline and experienced outward urban migration. The increased access to information and the opportunity provided to rural and remote companies to serve new markets by diminishing the impact of distance and time were the main benefits. In this view, the ICT is one instrument for company's development and for local development.

Our understanding of ICT infrastructure relates to the view of Lyytinen (1991), according to which information and communication technology is comprised of computing and telecommunication technologies and is associated with the know-how applied in different fields or organisational activity.

Simultaneously, the small and medium companies (SMEs) assume an important role in the regional and local economy. The SMEs are more flexible in adopting the new technologies and according to Julien (1995) some regions are developed based in the SMEs, where the employment, the added value and the exportations increased in the occidental economies. According to Vaz and Cesário (2003) the SMEs contributed to the middle actives and dynamics through network relationships with others companies. The importance of the SMEs to local development, particularly in peripheral regions is also evident in the work of Nicolas and Noronha (2000), Georgoudaki et. al (2003); Vaz and Cesário (2003).

Norris (2001) is one of the researchers who has focused on the economic and political aspects of avail- ability and usage of communication and information technology infrastructure, and has distinguished three hierarchical levels: the macro-level, the technological and economic resources available and their distribution, the meso-level, the role played by political institutions, and the micro-level, individual resources and individual motivation.

Thus, the aim of this paper is to present the results of an empirical research into the companies of the Côa' Region, that is located in the interior of Central Portugal and that relates the implementation and utilization of ICTs to their impact on the local dynamics of innovation, and to propose an analytical framework for the following goals: to generate local innovation and competitiveness using the ICT in SMEs.

\section{Hypotheses and Methodology}

In this paper we tried to analyse the situation of companies in Côa' Region in terms of innovations introduction and verify which conditions can generate more dynamism. For this purpose we considered the following factors, based on the third level presented by Norris (2001): (1) activity sector; (2) number of employees; (3) company dimension; sales volume; (4) year of establishment; (5) export activity; (6) management education; (7) customer/supplier relationship systems.

With the first factor we consider the fact that industry dynamics can moderate the innovation process; the second and third factors measure the dimension as a moderator as well; the fourth factor introduces the question of maturation process; the fifth factor measures the involvement in foreign markets as a driver for innovation; the sixth factor is managerial influence in this process, namely academic education, and the seventh factor tries to include prior development of ICT's as a moderator to more innovation investment (Chaves and Alves, 2004).

The Côa is a poor region in Portuguese and European terms in which a series of elements dominate: scarce technological base, reduced company size, a poor managerial attitude towards modernization and reluctant cooperation between companies' universities and investigation centres. Those characteristics limit the creation and diffusion of innovation and competitiveness development (Neto and Silva, 1999). This region covers part of two sub-regions and is constituted by eight councils of "Beira Interior Norte" and one of "Douro".

According to Stake (1995), the most unique aspect of a case study is the selection of cases to study. It 
was recognised that understanding of the phenomena depends on the appropriate choice of the cases. The study uses as methods of data gathering surveys with quantified responses that allows analysing the performance of the companies of this region relatively to the use of ICT. The sample we used for survey was based on a set of companies of the Portuguese Base of Establishments and Companies from the Portuguese National Institute of Statistics. The inquiries were directed to the managers personally by postal shipping and by e-mail. The information was recollected for the months January, February, March and April of 2003. In selecting the sample we considered all companies that had more than 10 employees.

\section{Data Treatment and Results}

In order to verify our hypothesis we began to group the companies using cluster analyses with the aim of verifying the different level of innovation present. We obtained three groups: the first, constituted by companies with higher innovation established; the second, with more limited innovations centred in marketing and the third, with an intermediate level of innovations (Table 1).

Based on the statistics in Table 2 we can verify that these different levels of innovation can significantly separate the companies studied and that the only variable which is not of significance is the new markets and increased market share type of innovation.

Based on this clustering we analysed our hypothesis by applying discriminate analysis. In Table 3 we can verify the results obtained. Two functions were estimated: the first explaining $93,2 \%$ of variance and the second 6,7 \%. By observing the Wilks' Lambda test we can verify that the first function is significant, but not the second.

In Table 4 we can see that this first discriminant function is related to the activity sector of the company, the dimension of the company and the managerial academic education. The other factor shown is associated with the second function which has not proven significance and includes the year of establishment, the export activity and the use of customer or supplier relationship systems. Based on the process of cross validation we can verify that the probability of correct classification is significantly higher than random probability.

Table 1. Cluster Analysis

\begin{tabular}{|l|c|c|c|}
\hline New products lines & 3 & 2 & 2 \\
\hline $\begin{array}{l}\text { New markets/increased market } \\
\text { share }\end{array}$ & 3 & 2 & 2 \\
\hline Procut quality improvement & 3 & 2 & 3 \\
\hline Increased operational flexibility & 3 & 0 & 2 \\
\hline Increased Production capacity & 3 & 0 & 2 \\
\hline Labour cost reduction & 2 & 0 & 1 \\
\hline Energy and Material reduction & 1 & 0 & 0 \\
\hline $\begin{array}{l}\text { Security and environment } \\
\text { improvement }\end{array}$ & 2 & 0 & 2 \\
\hline $\begin{array}{l}\text { Compliance with norms and } \\
\text { regulations }\end{array}$ & 3 & 0 & 2 \\
\hline Other innovations & 0 & 0 & 0 \\
\hline
\end{tabular}

Table 2. Cluster Analysis Anova

\begin{tabular}{|c|c|c|c|c|c|c|}
\hline & \multicolumn{2}{|c|}{ Cluster } & \multicolumn{2}{|c|}{ Error } & \multirow[b]{2}{*}{$\mathrm{F}$} & \multirow{2}{*}{ Sig. } \\
\hline & $\begin{array}{l}\text { Mean } \\
\text { Square }\end{array}$ & df & $\begin{array}{l}\text { Mean } \\
\text { Square }\end{array}$ & $\mathrm{df}$ & & \\
\hline New products lines & 3,81 & 2 & 1,31 & 27 & 2,91 & 0,07 \\
\hline New markets/increased market share & 2,38 & 2 & 1,42 & 27 & 1,69 & 0,20 \\
\hline Procut quality improvement & 3,92 & 2 & 1,04 & 27 & 3,78 & 0,04 \\
\hline Increased operational flexibility & 17,96 & 2 & 0,67 & 27 & 27,01 & 0,00 \\
\hline Increased Production capacity & 18,12 & 2 & 0,71 & 27 & 25,45 & 0,00 \\
\hline Labour cost reduction & 11,82 & 2 & 0,61 & 27 & 19,32 & 0,00 \\
\hline Energy and Material reduction & 3,11 & 2 & 0,39 & 27 & 8,02 & 0,00 \\
\hline Security and environment improvement & 15,34 & 2 & 0,77 & 27 & 20,03 & 0,00 \\
\hline Compliance with norms and regulations & 19,96 & 2 & 0,65 & 27 & 30,88 & 0,00 \\
\hline Other innovations & 0,39 & 2 & 0,59 & 27 & 0,66 & 0,53 \\
\hline
\end{tabular}


Table 3. Discriminant Analysis Functions and Wilks' Lambda

\begin{tabular}{|c|c|c|c|c|}
\hline \multicolumn{1}{|l|}{ Coefficients } \\
\hline Function & Eigenvalue & $\%$ of Variance & Cumulative \% & Canonical Correlation \\
\hline 1 & 2,822 & 93,216 & 93,216 & 0,859 \\
\hline 2 & 0,205 & 6,784 & 100,000 & 0,413 \\
\hline
\end{tabular}

First 2 canonical discriminant functions were used in the analysis.

Wilks' Lambda

\begin{tabular}{|c|c|c|c|c|}
\hline Test of Func & Wilks' Lambda & Chi-square & df & Sig. \\
\hline 1 through 2 & 0,217 & 48,879 & 14,000 & 0,000 \\
\hline 2 & 0,830 & 5,977 & 6,000 & 0,426 \\
\hline
\end{tabular}

Table 4. Discriminant Analysis Structure Matrix

\begin{tabular}{|l|c|c|}
\hline Functions & 1 & 2 \\
\hline Sectors & 0,40 & $-0,17$ \\
\hline Manager education & $-0,20$ & $-0,02$ \\
\hline Sales Volume & 0,15 & 0,00 \\
\hline $\begin{array}{l}\text { Customer/Supplier } \\
\text { relationship systems }\end{array}$ & 0,04 & 0,76 \\
\hline Export activity & $-0,10$ & $-0,30$ \\
\hline Company Dimension & 0,16 & 0,25 \\
\hline Year of Installation & 0,10 & 0,21 \\
\hline $63,3 \%$ of original grouped cases correctly classified \\
\hline $60,0 \%$ of cross-validated grouped cases correctly classified \\
\hline
\end{tabular}

We considered another set of variables, namely the type of cooperation relationships. In Table 5 we can observe that companies in group one are significantly different from companies in groups 2 and 3 regarding the cooperation with clients and consultants, while the reverse is true in terms of cooperation with public administration and other institutions.

Another aspect considered was the determination of these companies' principal sources of innovation information and the principal factors that limit innovation implementation. For this we used principal components of factor analysis. In Table $6 a$ we can see that in the case of information sources for innovation the four components were identified, explaining $71 \%$ of the variance and with a KMO of 0.67 .

Table 5. Anova - Cooperation

\begin{tabular}{|l|c|c|c|c|c|c|}
\hline \multirow{2}{*}{} & \multicolumn{7}{|c|}{ Clusters } & Dif. \\
\cline { 2 - 7 } & $\mathrm{F}$ & Sig. & $n=7$ & $n=13$ & $n=10$ & Clusters \\
\hline Affiliated Company & 0,98 & 0,39 & 1,67 & 0,88 & 0,88 & \\
\hline Suppliers & 1,08 & 0,35 & 2 & 1 & 1,13 & \\
\hline Clients & 2,63 & 0,09 & 2 & 0,63 & 0,75 & $1>2,3$ \\
\hline Competitors & 0,45 & 0,64 & 1,33 & 0,88 & 0,88 & \\
\hline Consultants & 2,17 & 0,13 & 1,67 & 0,5 & 0,75 & $1>2,3$ \\
\hline R\&D institutions & 1,59 & 0,22 & 1 & 0,63 & 1,5 & \\
\hline Universities & 0,56 & 0,58 & 1 & 0,63 & 1,13 & \\
\hline Development associations & 1,20 & 0,31 & 0,67 & 0,5 & 1,13 & \\
\hline Management associations & 0,73 & 0,49 & 0,67 & 1,38 & 1,38 & \\
\hline Public Administration & 3,66 & 0,04 & 0 & 0,25 & 1,13 & $3>1,2$ \\
\hline Local Administration & 1,37 & 0,27 & 1 & 0,38 & 1,13 & \\
\hline Unions & 2,53 & 0,09 & 0 & 0 & 0,5 & \\
\hline Other institutions & 2,78 & 0,08 & 1 & 0,38 & 1,5 & $3>2$ \\
\hline
\end{tabular}


Table 6a. Rotated Solution - Information Sources

\begin{tabular}{|c|c|c|c|c|c|c|}
\hline \multicolumn{5}{|c|}{ Initial Eigenvalues } & \multicolumn{3}{c|}{ Rotation Sums of Squared Loadings } \\
\hline Components & Total & \% of Variance & Cumulative \% & Total & \% of Variance & Cumulative \\
\hline 1 & 4,54 & 37,81 & 37,81 & 2,98 & 24,85 & 24,85 \\
\hline 2 & 1,65 & 13,74 & 51,55 & 2,02 & 16,86 & 41,71 \\
\hline 3 & 1,44 & 11,97 & 63,52 & 1,95 & 16,28 & 57,99 \\
\hline 4 & 1,01 & 8,45 & 71,97 & 1,68 & 13,98 & 71,97 \\
\hline 5 & 0,86 & 7,15 & 79,12 & & & \\
\hline 6 & 0,70 & 5,79 & 84,91 & & & \\
\hline 7 & 0,62 & 5,16 & 90,07 & & & \\
\hline 8 & 0,39 & 3,27 & 93,34 & & & \\
\hline 9 & 0,33 & 2,72 & 96,06 & & & \\
\hline 10 & 0,24 & 2,04 & 98,10 & & & \\
\hline 11 & 0,16 & 1,36 & 99,46 & & & \\
\hline 12 & 0,06 & 0,54 & 100,00 & & & \\
\hline & & & & & & \\
\hline
\end{tabular}

Table 6b. Factor Analysis - Information Sources

\begin{tabular}{|l|c|c|c|c|}
\hline \multicolumn{1}{|c|}{ Components } & 1 & 2 & 3 & 4 \\
\hline Professional networks & 0,79 & $-0,42$ & $-0,16$ & $-0,31$ \\
\hline Personal contacts & 0,76 & $-0,45$ & 0,29 & $-0,11$ \\
\hline Inside the company & 0,70 & $-0,48$ & $-0,23$ & 0,13 \\
\hline Clients & 0,69 & $-0,42$ & 0,19 & $-0,43$ \\
\hline R\&D Laboratories & 0,64 & 0,21 & 0,44 & $-0,45$ \\
\hline Consulting firms & 0,61 & 0,11 & & $-0,23$ \\
\hline Competitors & 0,60 & 0,39 & 0,16 & 0,42 \\
\hline Other companies & 0,55 & 0,38 & & 0,34 \\
\hline Suppliers & 0,55 & 0,23 & $-0,38$ & $-0,20$ \\
\hline Conferences and scientific journals & 0,53 & 0,51 & $-0,64$ & 0,24 \\
\hline Expositions & 0,42 & 0,42 & 0,60 & \\
\hline Universities & 0,40 & 0,19 & & \\
\hline
\end{tabular}

In Table $6 \mathrm{~b}$ we can view that the first component is associated with professional networks, personal contacts, inside the company and most sources of information, the second factor is related to expositions and universities, the third factor relates to consulting and other firms, while the fourth factor relates to.

In Table 7a we can see that this analysis of factors which are difficult in the innovation process shows that three components were identified, explaining $69 \%$ of the variance and with a KMO of 0,75 .

In Table $7 \mathrm{~b}$ we can view that the first component is associated with lack of clients acceptance, technology knowledge and market information, the second factor is related to financial means, risk perception and innovations costs while the third factor relates to market dimension, lack of cooperation efforts and low workers mobility. 
Table 7a. Factor Analysis - Innovation Difficulties

\begin{tabular}{|c|c|c|c|c|c|c|}
\hline \multicolumn{5}{|c|}{ Initial Eigenvalues } & \multicolumn{3}{c|}{ Rotation Sums of Squared Loadings } \\
\hline Components & Total & $\%$ of Variance & Cumulative \% & Total & \% of Variance & Cumulative \% \\
\hline 1 & 6,79 & 52,22 & 52,22 & 3,55 & 27,34 & 27,34 \\
\hline 2 & 1,13 & 8,72 & 60,94 & 2,74 & 21,05 & 48,40 \\
\hline 3 & 1,08 & 8,33 & 69,27 & 2,71 & 20,87 & 69,27 \\
\hline 4 & 0,91 & 6,96 & 76,23 & & & \\
\hline 5 & 0,82 & 6,33 & 82,56 & & & \\
\hline 6 & 0,63 & 4,87 & 87,42 & & & \\
\hline 7 & 0,49 & 3,77 & 91,19 & & & \\
\hline 8 & 0,35 & 2,68 & 93,88 & & & \\
\hline 9 & 0,28 & 2,18 & 96,06 & & & \\
\hline 10 & 0,19 & 1,48 & 97,54 & & & \\
\hline 11 & 0,15 & 1,16 & 98,70 & & & \\
\hline 12 & 0,12 & 0,95 & 99,65 & & & \\
\hline 13 & 0,05 & 0,35 & 100,0 & & & \\
\hline
\end{tabular}

Table 7b. Rotated Solution - Innovation Difficulties

\begin{tabular}{|l|c|c|c|}
\hline \multicolumn{1}{|c|}{ Components } & 1 & 2 & 3 \\
\hline Lack of clients acceptance & 0,83 & 0,22 & 0,10 \\
\hline Lack of technology knowledge & 0,82 & 0,16 & 0,40 \\
\hline Lack of market information & 0,75 & 0,33 & 0,36 \\
\hline Lack of trained personnel & 0,60 & 0,39 & 0,50 \\
\hline Inflexible organizational structure & 0,58 & 0,12 & 0,26 \\
\hline Excess norms and regulations & 0,54 & 0,51 & 0,16 \\
\hline Lack of financial means & 0,32 & 0,83 & 0,29 \\
\hline High risk perception & 0,30 & 0,81 & 0,21 \\
\hline High innovation costs & 0,10 & 0,76 & 0,81 \\
\hline Reduced market dimension & & 0,16 & 0,74 \\
\hline Lack of cooperation efforts & 0,13 & 0,27 & 0,68 \\
\hline Low workers mobility & 0,42 & 0,23 & 0,52 \\
\hline Low consumers expectations & 0,50 & 0,25 & \\
\hline
\end{tabular}

\section{Discussion and Conclusions}

From the analysis of the results presented above, we found disparities in the level of adoption of new technologies, managerial and technical expertise, training and exposure to available technologies and other infrastructures between organizations. In the organisations studied, the imbalances could be broadly attributed to differences in the sector of industry, management education and sales volume or dimension.

The elements of cooperation are also important and we could observe that companies in the first group we found, that hand more innovative aspects implemented were cooperating more with consultants and 
clients, while other groups of companies were more connected with public administration.

When analysing the different sources of information used by companies we could observe that companies would associate with professional networks, personal contacts and inside company information, while cooperation with universities and expositions seem to come together, and consulting and cooperation with other firms would be another route to information.

Considering the difficulties to implement innovations we can see three main types of problems that companies identify: the first component, that is associated with lack of clients' acceptance, company's technology knowledge and market information; the second factor, that is related to financial means, risk perception and innovations costs while the third factor relates to market dimension, lack of cooperation efforts.

In global terms after dividing the firms into three groups, the analysis shows that dimension and industry are aspects that constrain innovation along with management education and values. More innovative companies seek cooperation with consultants and clients and seem to be a reason for more difficulties in innovation derived from market dimension, lack of cooperative environment and low mobility that can be associated with more disfavoured regions.

\section{References}

1. CHAVES, R. A.; ALBA, J. R. (2004) The Role of the Innovation on ICT's In Regional Development: The Andalusian Case. XIV Jornadas Luso-Espanholas de Gestćo Cientkfica, realizadas na Universidade dos Aēores de 4 a 7 de Fevereiro, Aēores.

2. COURLET, C.; PECQUEUR, B. (1991) Systčmes Locaux d'Entreprises et Externalités: Essai de Typologie. Revue d'Economie Régionale et Urbaine - RERU, 3/4, p. 391-406.

3. GEORGOUDAKI, E.; DIMARA, E.; SKURAS, D. (2003) Worlds of Production ant the adoption of Communication and Information Technologies among Food SMEs in Lagging areas of Greece. In Conference "Small Firms Strategy for Innovation and Regional Problems,. Universidade do Algarve, 4 e 5 December.
4. JULIEN, P. A. (1995) Economic Theory, Entrepreneurship and New Economic Dynamics. In Conti et al eds. The Industrial Enterprise and Its Environment: Spatial Perspectives. Avebury, p. 123-142.

5. KOWALCZYKOWSKI, M. (2002) Disconnected Continent. Harvard International Review, 24(2), p. $40-43$.

6. LYYTINEN, K. (1991) Penetration of information technology in organizations; a comparative study using stage models and transaction costs. Scandinavian Journal of Information Systems, 3, p. 31-56.

7. NETO, P. (2002) Tecnologias de Informaēćo e Desenvolvimento Regional, Novas configuraẽões Relacionais e Novas Proximidades - o Processo de Construéćo de Memória do Território. IX Encontro Nacional da APDR, Lisboa 27 a 29 de Junho de 2002.

8. NETO, P.; BARROSO, J. (2003) As empresas e as TIC: estudo de caso do distrito de Évora. In Proceedings $X$ Encontro da APDR: Demografia e Desenvolvimento Regional, Evora.

9. NETO, P.; SILVA, P. (1999) A Cartografia Relacional e a Gestćo de Unidades Territoriais. Actas do VI Encontro Nacional da APDR, Regióes e Cidades na Unićo Europeia: que Futuro? Vol 1, Outubro, Coimbra, p. 587597.

10. NICOOLAS, F; NORONHA, M. T. (2000) State of Art in Instruments for Local Development, SMEs and VSMEs, Public Report D1: Contract nṛ HPSE-CT-199900024, Project INNOVALOC.

11. NORRIS, P. (2001) Digital Divide: Civic Engagement, Information Poverty, and the Internet Worldwide. Cambridge, UK; New York, NY, USA, Cambridge University Press.

12. OCDE (1997) National Innovation Systems. OECD Publications, Paris.

13. OECD (2001) Information and Communication Technologies and Rural Development. Territorial Economy. Available from Internet: <www.oecd.com>

14. PERSAUD, A. (2001) The Knowledge Gap. Foreign Affairs, 80, p. 107-117.

15. STAKE, R. E. (1995) The Art of Case Study Research. Thousand Oaks, CA: Sage.

16. VAZ, M. T.; CESĄRIO, M. I. (2003) Padrões Comportamentais dos Empresirios face a Inovaéćo: o caso das PMEs do Sector agro-alimentar localizadas no Alentejo Central e Oeste. Comunicaēćo Apresentada no X Encontro da APDR 26-28 Junho, Évora. 